\title{
Compressive strength of calcium silicate-based cement
}

\author{
Vanja Opačić Galić', Zoran Stamenić2, Violeta Petrović', Vukoman Jokanović3, Slavoljub Živković1 \\ 'University of Belgrade, School of Dental Medicine, Department for Restorative Dentistry and Endodontics, Belgrade, \\ Serbia; \\ ${ }^{2}$ University of Belgrade, Faculty for Mechanical Engineering, Department for General Machine Design, Belgrade, Serbia; \\ ${ }^{3}$ Vinca Institute of Nuclear Sciences, Department of Atomic Physics, Belgrade, Serbia
}

\begin{abstract}
SUMMARY
Introduction The aim of this study was to compare compressive strength (Cs) of new nanostructural calcium silicate based cement (nCS) with commercial calcium silicate cement and conventional GIC.

Methods Four nanostructural materials were tested: nanostructural calcium silicate based cement (nCS) (Jokanović et al.), MTA Plus (Cerkamed, Poland), Fuji IX (GC Corporation, Japan) and Ketac Universal Aplicap (3M ESPE, USA). Five samples of each material were mixed in accordance with manifecturer's guidelines and positioned in metal moulds $(\varphi 4 \mathrm{~mm}$ and $6 \mathrm{~mm})$. Compressive strength (Cs) expressed in MPa was determined after 24 hours, 7 days and 28 days respectively. Measurements were performed on universal testing equipment (Tinius Olsen, USA) at a crosshead speed of $1 \mathrm{~mm} / \mathrm{min}$. For processing the results one-way ANOVA and post-hoc test were used.

Results The highest values of compressive strength after $24 \mathrm{~h}$ was found in conventional GIC Fuji IX (mean 38.56 \pm 13.31 ) and Ketac Universal (mean 40.77 \pm 7.96 ). Calcium silicate cements after $24 \mathrm{~h}$ showed low values of compressive strength (MTA Plus 5.91 $\pm 0.28 \mathrm{MPa}$, nCS 1.35 $\pm 0.36 \mathrm{MPa}$ ). After 7 days, FUJI IX 47.42 $\pm 9.33 \mathrm{MPa}$ and Ketac Universal $35.25 \pm 10.60$ MPa showed higher value of compressive strength than MTA Plus $(15.09 \pm 2.77 \mathrm{MPa})$ and $\mathrm{nCS}(11.06 \pm 0.88 \mathrm{MPa})$. After 28 days the $\mathrm{Cs}$ value for conventional GIC Fuji IX was 48.03 $\pm 7.82 \mathrm{MPa}$ and Ketac Universal 36.65 $\pm 11.13 \mathrm{MPa}$ while for calcium silicate cements it was $16.47 \pm 1.89 \mathrm{MPa}$ and $\mathrm{nCS} 14.39 \pm 1.63 \mathrm{MPa}$. There was statistically significant difference $(\mathrm{p}<0.05)$ in Cs between conventional GIC and CS cements after $24 \mathrm{~h}, 7$ and 28 days.

Conclusions Calcium silicate cements initially showed lower values of compressive strength than conventional GIC that increased over time.
\end{abstract}

Keywords: calcium silicate cement; nanoparticle; glass ionomer cement; compressive strength

\section{INTRODUCTION}

Ideal material for root reparation should be able to close communication between the root canal and surrounding tissue, is biocompatible, dimensionally stable and insoluble when in contact with tissue fluids. The material is often placed in the root with an acidic environment, frequently with bacterial inflammation; therefore low $\mathrm{pH}$ level is an important factor that adds to the hardness and other properties of the cement [1]. In the past, materials such as calcium hydroxide, zinc oxide eugenol cements, resin composites, glass ionomer cements have been used for root canal perforation treatment but not all of them meet criteria of an ideal material [2].

GIC are developed by combining two different cements: silicate and zinc polycarboxyilate cements [3]. Conventional GIC are made by an acid-base reaction of glass ions with a water solution of polyacrylic acid. They are considered potential biomaterials for orthopedic application because of their ability to adhere to bone and metals and good stability in wet environment. However, lack of bioactive potential and poor mechanical characteristics are some of the issues of this cement.
In the past few years, biocompatible calcium silicate hydraulic cements have been introduced in endodontic therapy. Mineral trioxide aggregate (MTA) is usually used as biomaterial for root and functional perforation reparation, as well as in other indications [4]. MTA is a bioactive material that forms an apatite layer on its surface when in contact with phosphates from tissue liquids but it also forms hybrid layer between dentin and calcium silicate materials [5]. It also releases some of its components in phosphate saliva puffers that encourage biomineralization processes [6]. There are number of calcium silicate cements on the market with the goal to surpass the deficiencies of the original formulation. MTA Plus is a nanostructural MTA released in 2012, with shorter binding time and lower concentration of heavy metals (up to 90\%) in its formulation.

Nanoparticles allow uniform and homogenous structure, as well as lower temperature release while hydrating the cement (source: manufacturer). The use of nanoparticles has become an important research aspect in dentistry, with the focus on improving mechanical characteristics and antibacterial effect of the particles. The size of nanomaterial particles $(<100 \mathrm{~nm})$ that is similar to the size of

Address for correspondence: Vanja OPAČIĆ GALIĆ, School of Dental Medicine, Department for Restorative Dentistry and Endodontics, Rankeova 4, 11000 Belgrade, Serbia; vanja.opacic.galic@gmail.com 
Table 1. Force $(\mathrm{N})$ needed to break samples after $24 \mathrm{~h}, 7$ and 28 days

Tabela 1. Vrednosti sile (N) koje dovode do lomljenja uzorka posle 24 sata, 7 i 28 dana

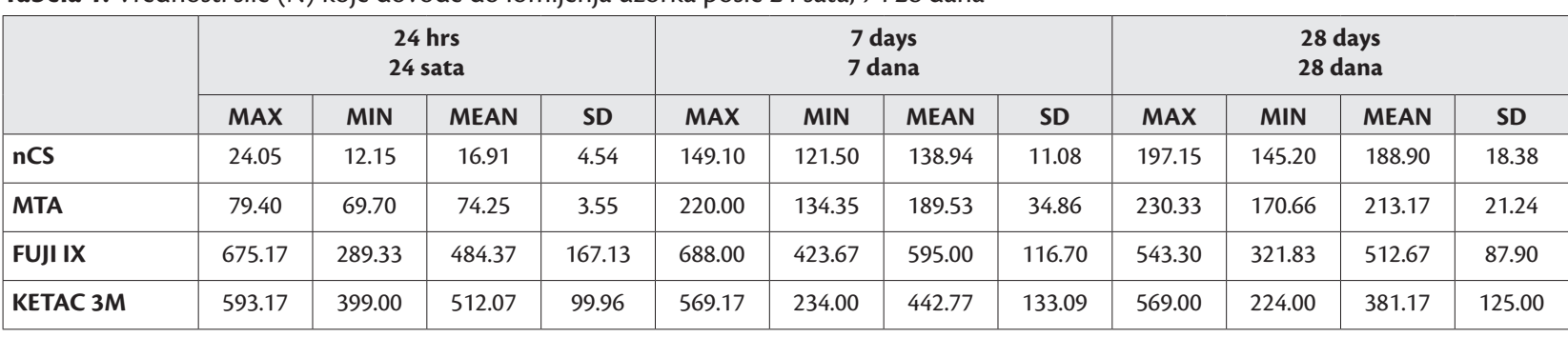

biological molecules and structures (proteins, DNA, water) indicates possible uses in biomedical researches.

Newly synthesized nanostructural material used in our study uses tri-calcium and di-calcium silicates as a base. This calcium silicate system is produced with hydrothermal sol-gel method and self-expanding burning reaction [7], which secures its high activity and short bonding time. The smallest parts of this system are about $19.9 \mathrm{~nm}$ and show notable system activity $[8,9]$.

Compressive strength tests are used in dentistry for simulations of masticatory forces that clinically affect restoration or materials for covering or replacing tissue. The majority of masticatory forces are of compressive nature and their exact value is hard to determine.

The aim of this study was to test the compressive strength of a newly synthesized nanostructural CS cement and compare it to the commercial MTA Plus and conventional GIC that are used in functional or crown perforation reparations. The null hypothesis was that there was no difference in compressive strength between conventional and calcium silicate cements.

\section{MATERIAL AND METHODS}

Four cements were used in the research: nanostructural calcium silicate system (nCS) (Jokanovic et al.) where 60\% of the total mass were $\beta-\mathrm{C}_{2} \mathrm{~S}_{\text {i }} \mathrm{C}_{3} \mathrm{~S}$ phases, $20 \%$ calcium carbonate and $20 \% \mathrm{BaSO}_{4}$ (Merck, Germany) as X-ray contrast. Water/powder mixing ratio was 1:2; MTA Plus (Cerkamed, Poland) hand mixed in the ratio 0,34g distilled water and 1gMTA powder; conventional GIC Fuji IX (GC Corporation, Japan), by the product instructions mechanically mixed in capsules for 10 seconds in an amalgamator at $4500 \mathrm{rpm}$; and self-adhesive and self-bonding GIC Ketak Universal Aplicap (3M ESP, USA), with glass oxides and liquid component that consisted of copolymer of acrylic and maleic acid and tartaric acid. As per manufacturer's instruction the capsules were mechanically mixed for 10 seconds in an amalgamator at $4500 \mathrm{rpm}$.

\section{Sample preparation}

After mixing all materials were placed in two parted metal moulds $4 \mathrm{~mm}$ in diameter and $6 \mathrm{~mm}$ tall and they were condensed with a hand plunger, 5 samples for each material. The samples were kept on $37^{\circ} \mathrm{C}$ in a steam bath for $24 \mathrm{~h}, 7$ and 28 days. All cylindrical samples were polished with the finest abrasive paper and minimal pressure and
Table 2. Compressive strength $(\mathrm{Cs})$ values $(\mathrm{MPa})$ of the tested materials in the function of time

Tabela 2. Vrednosti kompresivne čvrstoće ( $\mathrm{MPa}$ ) testiranih materijala u funkciji vremena

\begin{tabular}{|l|c|c|c|}
\hline & $\begin{array}{c}\mathbf{2 4} \text { hrs } \\
\mathbf{2 4} \text { sata }\end{array}$ & $\begin{array}{c}\mathbf{7} \text { days } \\
\mathbf{7} \text { dana }\end{array}$ & $\begin{array}{c}\mathbf{2 8} \text { days } \\
\mathbf{2 8} \text { dana }\end{array}$ \\
\hline nCS & $1.35 \pm 0.36$ & $11.06 \pm 0.88$ & $14.39 \pm 1.63$ \\
\hline MTA & $5.91 \pm 0.28$ & $15.09 \pm 2.77$ & $16.47 \pm 1.89$ \\
\hline FUJI IX & $38.56 \pm 13.31$ & $47.42 \pm 9.33$ & $48.03 \pm 7.82$ \\
\hline KETAC 3M & $40.77 \pm 7.96$ & $35.25 \pm 10.60$ & $36.65 \pm 11.13$ \\
\hline
\end{tabular}

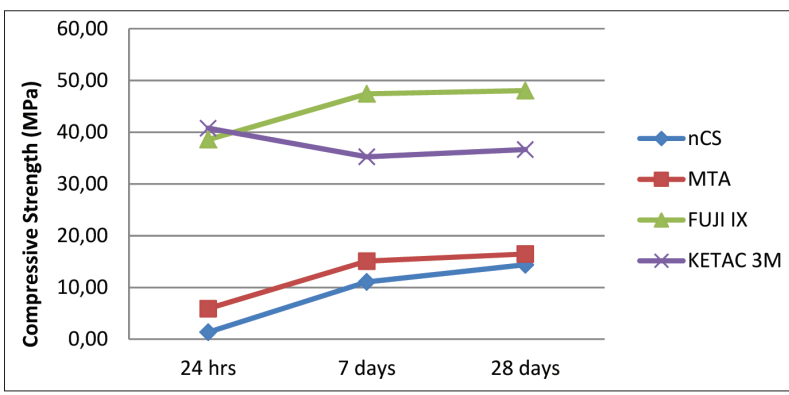

Figure 1. Compressive strength values $(\mathrm{MPa})$ in the function of time Slika 1. Vrednosti kompresivne čvrstoće ( $\mathrm{MPa}$ ) u funkciji vremena nCS - nanostructural calcium silicate cement nCS - nanostrukturni kalcijum-silikatni cement

visually checked. Samples with visible structural damage were eliminated from the study.

Compressive strength testing was done according to international standard ISO 9917-1:2007 (Dentistry-waterbased cements- Part 1: powder/liquid acid-base cements) using a universal test machine (Tinius Olsen, USA; 5KN) at the speed of $1 \mathrm{~mm} / \mathrm{min}$ along the longer axis of cylindrical samples [10]. The force needed to break the sample was noted and compressive strength in MPa was calculated with the formula $\mathrm{Cs}=4 \mathrm{P} / \pi \mathrm{d}$ where $\mathrm{P}$ was the maximum force needed to break the sample measured in $\mathrm{N}$, and $\mathrm{d}$ was the diameter in $\mathrm{mm}$.

For processing the results one-way ANOVA and posthoc test was used. The level of significance was set at $\mathrm{p}<0.05$.

\section{RESULTS}

The results are showed in the Tables 1-2 and Figure 1. The highest values of compressive strength after $24 \mathrm{~h}$ were shown by conventional GIC Fuji IX (mean 38.56 \pm 13.31 ) and Ketac Universal (mean 40.77 \pm 7.96 ), but without sta- 
tistical difference between them. Calcium silicate cements showed low values of compressive strength (MTA Plus $5.91 \pm 0.28 \mathrm{MPa}$ and nCS $1.35 \pm 0.36 \mathrm{MPa}$ ), without statistical difference. A statistically significant difference was noticed between GIC and CS cements $(p<0.05)$.

After 7 days, the highest compressive strength value was shown by FUJI IX $47.42 \pm 9.33 \mathrm{MPa}$ and Ketak Universal $35.25 \pm 10.60 \mathrm{MPa}$, but without a statistically significant difference between them. The compressive strength of MTA Plus was $15.09 \pm 2.77 \mathrm{MPa}$ and nCS $11.06 \pm 0.88$ $\mathrm{MPa}$, without statistically significant difference. There was a statistically significant difference between conventional GIC and CS cements $(\mathrm{p}<0.05)$.

After 28 days Cs value for conventional GIC Fuji IX was $48.03 \pm 7.82 \mathrm{MPa}$ and Ketak Universal 36.65 $\pm 11.13 \mathrm{MPa}$. There was no statistically significant difference between them. After four weeks, an increase in Cs value was noticed in calcium silicate cements, MTA Plus $16.47 \pm 1.89$ $\mathrm{MPa}$, and nCS $14.39 \pm 1.63 \mathrm{MPa}$ but without statistically significant difference between them. Between the conventional GIC and CS cements there was a statistically significant difference $(\mathrm{p}<0.05)$.

\section{DISCUSSION}

Compressive strength is an indirect measure of bonding and strength of the material $[11,12]$. It is an important property that may affect clinical performance [13]. This factor plays an important role in the treatment of functional perforations where cements are directly exposed to occlusal forces [14].

In the literature, significant variations in measured comprehensive strength have been reported as numerous factors can affect it. The cylindrical shape of the samples is convenient but sample surface perfection and intimate contact between samples and testing machine is hard to achieve [8]. Also, the size and shape of the samples, the preparation of the samples and hydration time, water/ powder ratio, mixing technique, pressure while compacting, as well as the moisture and temperature of the room affect results $[15,16]$.

Conventional GIC are in wide use in clinical practice as cements or restorative materials. Many researches have been done with the goal to enhance mechanical and biological properties of GIC with incorporation of bioactive ceramic particles, glass powder and similar. Adding Zn has shown to have a stimulating effect on bone formation in in vitro and in vivo conditions, as well as antibacterial activity, similar to silver. Adding $\mathrm{MgO}$ increased cell proliferation [3]. Titanium oxide is added because it is chemically stable, biocompatible and has antibacterial properties, and has shown significant activity against Streotococcus mutans in nano-formulation [8].

It has been confirmed in our research, as well as by other researchers, that cement reaction continues after one day, because crosswise bonds are established in the cement matrix [3]. Shiowaza [17] pointed out that cement maturation (acid-base reaction) is continued in the first week that can be seen as an increase in compressive strength and it is then stable for the next 12 months. These results are consistent with the results of our research, where there was no further compressive strength value increase between 7 and 28 days.

Compressive strength is considered as one of the most important physical properties of hydraulic cements and it is in correlation with the degree of hydration [2], where hydration reaction is the key for hardening of hydraulic silicate cements.

Compressive strength of calcium silicate cements is initially, after $24 \mathrm{~h}$ low. Bonding and hardening of the hydraulic cements depends on the formation of the CSH gel and ettringate (hydrated calcium sulfoaluminate) on the nucleation points of calcium hydroxyl crystals [18]. The presence or absence of these crystal formations (ettringate crystals) in different formulations of calcium silicate cements is probable reason for different values of compressive strengths between them [2]. In the ISO standard compressive strengths are still not defined for pulp covering or perforation materials, there is only a suggestion that materials are to be compared to the value of stress that occurs during amalgam condensation [19]. After seven days, the value of compressive strength of calcium silicate cements increases, where Cs of nCS further increases even after 28 days due to cement hydration.

The difference in compressive strength values between materials with similar or even the same composition can be explained by the size of the particles [11,19], as well as experimental conditions. That is how Akbari et al. [6] found that the Cs of White MTA (Angelus, Brazil) was 1.16 MPa after 24h and 2.19 MPa after 7 days, while Natale et al. [20] found Cs to be $18 \mathrm{MPa}$ after 7 days. Noh et al. [21] found that WMTA (ProRoot MTA) after 24h had an average value of 19.41 and after 7 days $46.18 \mathrm{MPa}$, while Basturk et al. [16] showed results as high as $84.17 \mathrm{MPa}$ after 4 days for ProRoot MTA. The microstructure and homogenicity of the cement affect its strength because finer particles have greater ability to absorb moisture.

Hand mixing of materials can result in inadequate hydration due to the limited formation of micropores inside the material that compromise water penetration in the material. Mitchell and Douglas pointed out that hand mixed cements have lower comprehensive strength due to trapped air, while capsulated cements mixed in a centrifuge have higher Cs $[22,16]$.

Nanostructural materials have particles that are not over $100 \mathrm{~nm}$ in size (most often between 5 and $50 \mathrm{~nm}$ ), but therefore have up to ten times bigger surface area, which stimulates greater ettringate crystal formation [23]. Nanostructures strive to solve one of the key problems of endodontic cements like bonding time. Experiments indicate that in almost all nano-powders kinetic absorption and desorption can be improved simply by reducing the particle size [14].

Perfecting materials that can be used as biological bone "substitutes" is currently one of the most valuable and most active fields of biomaterial research. Biocompatibility and bioactivity of these materials secure the interaction with biological systems. Bioactive materials like calcium silicate cements, especially with nanostruc- 
ture, stimulate regeneration of damaged tissue, therefore renewing the function of damaged tissue or organs [7].

\section{CONCLUSION}

The null hypothesis that there is no difference in Cs between conventional and calcium silicate cements is rejected. The compressive strength of conventional glass ionomer cements was significantly higher after $24 \mathrm{~h}$, increased after 7 days and remained the same after 28 days. MTA Plus showed higher compressive strength after $24 \mathrm{~h}$ and 7 days than newly synthesized nanostructural calcium silicate cement (nCS) but the values were similar after 28 days. Compressive strength of calcium silicate cement grows with time and cement hydration.

\section{ACKNOWLEDGMENTS}

The authors are grateful to Primarius (Dentistry\&Medicine) for supplying the materials used in this study. The authors deny any conflicts of interest related to this study.

\section{REFERENCES}

1. Wang Z, Ma J, Shen Y, Haapasalo M. Acidic pH weakens the microhardness and microstructure of three tricalcium silicate materials. Int Endod J. 2015; 48:323-32. [DOl: 10.1111/iej.12318] [PMID: 24871586]

2. Kayahan MB, Nekoofar MH, McCann A, Sunay H, Kaptan RF, Meraji N, et al. Effect of Acid Etching Procedures on the Compressive Strength of Calcium Silicate-based Endodontic Cements. J Endod. 2013; 39(12):1646-48. [DOI: 10.1016/j.joen.2013.09.008] [PMID: 24238465]

3. Kim DA, Abo-Mosallam H, Lee HY, Lee JH, Kim HW, Lee HH. Biological and mechanical properties of an experimental glassionomer cement modified by partial replacement of $\mathrm{CaO}$ with MgO or ZnO. J Appl Oral Sci. 2015; 23(4):369-75

[DOI: 10.1590/1678-775720150035] [PMID: 26398508]

4. Parirokh M, Torabinejad M. Mineral trioxide aggregate: a comprehensive literature review-Part I: Chemical, physical and antibacterial properties. J Endod. 2010; 36(1):16-27.

[DOI: 10.1016/j.joen.2009.09.006] [PMID: 20003930]

5. Elnaghy AM. Influence of Acidic Environment on Properties of Biodentine and White Mineral Trioxide Aggregate: A Comparative Study.J Endod. 2014; 40(7):953-7. [DOI: 10.1016/j.joen.2013.11.007] [PMID: 24935542]

6. Akbari M, Zebarjad SM, Nategh B, Rouhani A. Effect of Nano Silica on Setting Time and Physical Properties of Mineral Trioxide Aggregate. J Endod. 2013; 39(11):1448-51.

[DOI: 10.1016/j.joen.2013.06.035] [PMID: 24139272]

7. Opačić-Galić V, Petrović V, Živković S, Jokanović V, Nikolić B, Knežević-Vukčević ], et al. New nanostructural biomaterials based on active silicate systems and hydroxyapatite: charaterization and genotoxicity in human peripheral blood lymphocytes. Int Endod J. 2013; 46(6):506-16. [DOI: 10.1111/iej.12017] [PMID: 23173688]

8. Contreras RG, Scougall-Vilchis RJ, Contreras-Bulnes R, Sakagami $\mathrm{H}$, Morales-Luckie RA, Nakajima H. Mechanical, antibacterial and bond strength properties of nano-titanium-enriched glass ionomer cement. J Appl Oral Sci. 2015; 23(3):321-8. [DOI: 101590/1678-775720140496] [PMID: 26221928]
9. Grech L, Mallia B, Camilleri J. Investigation of the physical properties of tricalcium silicate cement-based root-end filling materials. Dental Materials. 2013; 29:e20-8. [DOI: 10.1016/j.dental.2012.11.007] [PMID: 23199808]

10. International Standards Organization. ISO 9917-1. Dentistry-waterbased cements. Part 1: powder/liquid acid-base cements; 2007.

11. Basturk FB, Nekoofar MH, GündayM, Dummer PM. The Effect of Various Mixing and Placement Techniques on the Compessive Strength of Mineral Trioxide Aggregate. J Endod. 2013; 39(1):111-4. [DOI: 10.1016/j.joen.2012.09.007] [PMID: 23228268]

12. Walsh RM, Woodmansey KF, Glickman GN, He J. Evaluation of Compressive Strength of Hydraulic Silicate-based Root-end Filling Materials. J Endod. 2014; 40(7):969-72.

[DOI: 10.1016/j.joen.2013.11.018] [PMID: 24935545]

13. Li Y, Lin $H$, Zheng G, Zhang $X, X u$ Y. A comparison study on the flexural strength and compressive strength of four resin-modified luting glass ionomer cements. Bio-Medical Materials and Engineering. 2015; 26:S9-17. [DOI: 10.3233/BME-151284] [PMID: 26406090]

14. Saghiri MA, Garcia-Godoy F, Asatourian A, Lotfi M, Banava S, Khezri-Boukani K. Effect of $\mathrm{pH}$ on compessive strength of some modification of mineral trioxide aggregate. Med Oral Patol Oral Cir Bucal. 2013; 18(3):e714-20. [DOI: 10.4317/medoral.18922] [PMID: 23722137]

15. Grazziotin-Soares R, Nekoofar MH, Davies TE, Bafail A, Alhaddar E, Hübler R, et al. Effect of bismuth oxide on white mineral trioxide aggregate: chemical characterization and physical properties. Int Endod J. 2014; 47(6):520-33. [DOI: 10.1111/iej.12181] [PMID: 24025109]

16. Basturk FB, Nekoofar MH, Gunday M, Dummer PMH. Effect of Varying Water-to-Powder Ratios and Ultrasonic Placement on the Compressive Strength of Mineral Trioxide Agreggate. J Endod. 2015; 41(4):531-4. [DOI: 10.1016/j,joen.2014.10.022] [PMID: 25576207]

17. Shiozawa M, Takahashi H, Iwasaki N. Fluoride release and mechanical properties after 1-year water storage of recent restorative glass ionomer cements. Clin Oral Invest. 2014; 18(4):1053-60. [DOl: 10.1007/s00784-013-1074-4] [PMID: 23974799]

18. Oloomi K, Saberi E, Mokhtari H, Mokhtari Zonouzi HR, Nosrat A, Nekoofar MH, et al. Evaluation of the effect of blood contamination on the compressive strength of MTA modified with hydration accelerators. Restorative Dent Endod. 2013; 38(3):128-33. [DOI: 10.5395/rde.2013.38.3.128] [PMID: 240010078]

19. Lee JB, Park S), Kim HH, Kwon YS, Lee KW, Min KS. Physical properties and biological/odontogenic effects of an experimentally developed fast-setting $\boldsymbol{a}$-tricalcium phosphate-based pulp capping material. BMC Oral Health. 2014; 14:87. [DOI: 10.1186/1472-6831-14-87] [PMID: 25015173]

20. Natale LC, Rodrigues MC, Xavier TA, Simões A, De Souza DN, Braga RR. Ion release and mechanical properties of calcium silicate and calcium hydroxide materials used for pulp capping. Int Endod J. 2015; 48(1):89-94. [DOI: 10.1111/iej.12281] [PMID: 24646329]

21. Noh YS, Chung SH, Bae KS, Baek SH, Kum KY, Lee WC, et al. Mechanical properties and microstructure analysis of mineral trioxide aggregate mixed with hydrophilic synthetic polymer. J Biomed Mater Res Part B. 2015; 103(4):777-82. [DOI: 10.1002/jbm.b.33257] [PMID: 25132636]

22. Molina GF, Cabral RJ, Mazzola I, Brain Lascano L, Frencken JE. Mechanical performance of encapsulated restorative glass-ionomer cements for use with Atraumatic Restorative Treatment (ART). J Appl Oral Sci. 2013; 21(3):249-9. [DOI: 10.1590/1679775720130129] [PMID: 23857657]

23. Saghiri MA, Gutmann JL, Orangi J, Asatourian A, Sheibani N. Radiopacifier Particle Size Impacts the Physical Properties of Tricalcium Silicate-based Cements. J Endod. 2015; 41(2):225-30. [DOl: 10.1016/j,joen.2014.09.025] [PMID: 25492489] 


\title{
Ispitivanje kompresivne čvrstoće kalcijum-silikatnih cemenata
}

\author{
Vanja Opačić Galić1, Zoran Stamenić², Violeta Petrović', Vukoman Jokanović3, Slavoljub Živković1 \\ 'Univerzitet u Beogradu, Stomatološki fakultet, Klinika za bolesti zuba, Beograd, Srbija; \\ ${ }^{2}$ Univerzitet u Beogradu, Mašinski fakultet, Katedra za opšte mašinske konstrukcije, Beograd, Srbija; \\ ${ }^{3}$ Univerzitet u Beogradu, Institut za nuklearne nauke „Vinča“, Laboratorija za atomsku fiziku, Beograd, Srbija
}

\begin{abstract}
KRATAK SADRŽAJ
Uvod Cilj ovog rada je bio da se proveri kompresivna čvrstoća (KČ) novog nanostrukturnog kalcijum-silikatnog cementa (nCS) i uporedi sa komercijalnim kalcijum-silikatnim cementom i konvencionalnim GJC u funkciji vremena.

Materijal i metod Testirana su četiri materijala - nanostrukturni CS (Jokanović i sar.), MTA Plus (Cerkamed, Poland), Fuji IX (GC Corporation, Japan) and Ketac Universal Aplicap (3M ESPE, USA). Po pet uzoraka za svaki materijal je zamešano po proizvođačkom uputstvu i postavljano u metalne kalupe ( $\varphi 4 \mathrm{~mm}$ i $6 \mathrm{~mm}$ visoke). KČ, izražena u megapaskalima, merena je posle 24 sata i posle 7 i 28 dana na univerzalnoj test mašini (Tinius Olsen, USA) sa brzinom utiskivača od $1 \mathrm{~mm} / \mathrm{min}$. Dobijeni rezultati su statistički obrađeni one-way ANOVA i post hoc Tukeys testovima.

Resultati Posle 24 sata najveću KČ imao je FUJI IX (38,56 \pm 13,31 MPa), zatim Ketac Univerzal (40,77 $\pm 7,96 \mathrm{MPa})$. Kalcijum-silikatni cementi su pokazali niže vrednosti KČ 24 sata posle mešanja i to MTA 5,91 $\pm 0,28$, a nCS 1,35 $\pm 0,36 \mathrm{MPa}$. Posle sedam dana KČ za FUJI IX je bila 47,72 $\pm 9,33 \mathrm{MPa}$, a za Ketac Universal 35,25 \pm 10,60 MPa, dok je vrednost za MTA bila 15,09 $\pm 2,77 \mathrm{MPa}$, a nCS 11,06 $\pm 0,88$. Posle 28 dana KČ za FUJI IX je bila 48,03 $\pm 7,82 \mathrm{MPa}$, a za Ketac $36,65 \pm 11,13 \mathrm{MPa}$. KČ kalcijum-silikatnih cemenata posle 28 dana je bila 16,47 $\pm 1,89$ za MTA, a za nCS 14,39 $\pm 1,63 \mathrm{MPa}$, bez statističi značajne razlike između njih. Između konvencionalnih GJC i CS cemenata postoji statistički značajna razlika $(p<0,05)$ posle $24 \mathrm{~h}$, kao i posle 7 i 28 dana.

Zaključak Kalcijum-silikatni cementi su inicijalno pokazali niže vrednosti KČ u odnosu na konvencionalne GJC, ali su se one povećavale u funkciji vremena.

Ključne reči: kalcijum-silikatni cement; nanočestice; glasjonomer cement; kompresivna čvrstoća
\end{abstract}

\section{UVOD}

Idealan materijal za reparaciju oštećenja korena zuba treba da omogući zatvaranje komunikacije između kanala korena i okolnog tkiva, da je biokompatibilan, dimenziono stabilan i nerastvorljiv u kontaktu sa tkivnim fluidima. Materijal se često plasira u koren, gde je kiselo okruženje, a često i sa bakterijskom inflamacijom, pa je nizak pH važan faktor koji utiče na tvrdoću i druga svojstva cemenata [1]. Dugi niz godina u terapiji perforacija kanala korena se koriste različiti materijali kao što su kalcijum-hidroksid, cink-oksid eugenol cementi, kompozitne smole, glasjonomer cementi, ali nijedan u potpunosti ne ispunjava zahteve idealnog materijala [2].

GJC su razvijeni iz kombinacije dva različita cementa: silikatnih i cink-polikarboksilatnih [3]. Konvencionalni GJC nastaju acido-baznom reakcijom jona stakla sa vodenim rastvorom poliakrilne kiseline i u širokoj su upotrebi u kliničkoj praksi. Smatraju se potencijalnim biomaterijalima za ortopedske aplikacije zbog njihove sposobnosti da adheriraju na kost i metale i stabilnosti u vlažnoj sredini. Ipak, nedostatak bioaktivnog potencijala i loše mehaničke osobine još su uvek nerešivi.

Poslednjih godina se u endodontsku terapiju uvode izrazito biokompatibilni kalcijum-silikatni hidraulični cementi. Mineral trioksid agregat (MTA) uobičajeno se koristi kao biomaterijal za reparaciju korenskih i furkacionih perforacija, ali i u drugim indikacijama [4]. MTA je bioaktivan materijal koji na svojoj površini formira apatitni sloj u kontaktu sa fosfatima iz tkivnih tečnosti, ali i hibridni sloj između dentina i kalcijum-silikatnih materijala [5]. On takođe otpušta neke od svojih komponenti u fosfatne pufere pljuvačke, čime podstiče procese biomineralizacije [6]. Na tržištu postoji veći broj kalcijum-silikatnih cemenata sa ciljem da se prevaziđu neki nedostaci izvorne formulacije. MTA Plus je nanostrukturni MTA predstavljen 2012. godine, sa kraćim vremenom vezivanja i smanjenjem sadržaja teških metala (i do 90\%) u svojoj formulaciji. Nanočestice omoguća- vaju uniformnu i homogenu strukturu, kao i oslobađanje niže toplote prilikom hidratacije cementa (izvor: proizvođač).

Upotreba nanopartikula je postala značajan aspekt istraživanja u stomatologiji, sa fokusom na poboljšanje mehaničkih osobina i antibakterijski efekat tih čestica. Sama veličina čestica nanomaterijala (<100 nm), koja je slična veličini bioloških molekula i struktura (proteini, organele, molekul DNK i vode), upućuje na moguću primenu nanomaterijala u biomedicinskim istraživanjima.

Novosintetisani nanostrukturni materijal korišćen u ovom radu je na bazi trikalcijum i dikalcijum silikata. Ovaj kalcijumsilikatni sistem je dobijen hidrotermalnom sol-gel metodom i samoširećom reakcijom sagorevanja [7], što mu je obezbedilo visoku aktivnost i kratko vreme vezivanja. Najmanji deo ovog sistema su kristaliti veličine oko 19,9 nm, koji pokazuju značajnu aktivnost sistema.

Testovi kompresivne čvrstoće (KČ) koriste se u stomatologiji za laboratorijsku simulaciju stresa koji je posledica sila koje klinički deluju na restaurativne materijale, ili materijale za prekrivanje i nadoknadu tkiva. Većina mastikatornih sila su kompresivne prirode i njihovu tačnu vrednost je teško utvrditi $[8,9]$.

Cilj ovog rada je bio da se proveri KČ novosintetisanog nanostrukturnog CS cementa i uporedi sa komercijalnim MTA Plus i najčešće korišćenim konvencionalnim GJC koji se koriste u reparaciji furkacionih ili kruničnih perforacija. Nulta hipoteza je da nema razlike u KČ između konvencionalnih i kalcijumsilikatnih cemenata.

\section{MATERIJAL I METOD}

U istraživanje su uključena četiri cementa:

Nanostrukturni kalcijum-silikatni sistem (nCS) (Jokanović i sar.) sadrži 60\% ukupne količine $\beta-\mathrm{C}_{2} \mathrm{~S}_{\text {i }} \mathrm{C}_{3} \mathrm{~S}$ faza, $20 \%$ kalcijum-karbonata i 20\% $\mathrm{BaSO}_{4}$ (Merck, Nemačka) kao rendgen 
kontrastno sredstvo. Prah je mešan sa destilovanom vodom $\mathrm{u}$ odnosu $1: 2$ voda : prah.

MTA Plus (Cerkamed, Poljska) ručno je mešan u odnosu $0,34 \mathrm{~g}$ destilovane vode sa $1 \mathrm{~g}$ praha MTA.

Konvencionalni GJC Fuji IX (GC Corporation, Japan) - prema uputstvu proizvođača mehanički su mešane kapsule 10 sek. $\mathrm{u}$ amalgamatoru na $4500 \mathrm{rpm}$.

Samoadhezivni i samovezujući GJC Ketak Universal Aplicap (3M ESP, USA), sa oksidima stakla, a tečna komponenta je kopolimer akrilne i maleične kiseline i vinska kiselina. Prema proizvođačkom uputstvu kapsule su mehanički mešane 10 sek. u amalgamatoru na $4500 \mathrm{rpm}$.

\section{Priprema uzoraka}

Materijali su nakon mešanja plasirani u dvodelne metalne kalupe promera $4 \mathrm{~mm}$ i visoke $6 \mathrm{~mm}$, gde su kondenzovani ručnim nabijačem, po pet uzoraka za svaki materijal. Uzorci su držani na $37 \mathrm{C}$ u parnom kupatilu 24 sata, 7 i 28 dana. Svi cilindrični uzorci su polirani najfinijim abrazivnim papirom sa minimalnim pritiskom i vizuelno proveravani, a uzorci sa oštećenjima u strukturi su odbačeni.

Testiranje KČ testiranih materijala je sprovedeno u skladu sa međunarodnim standardom ISO 9917-1:2007 (Dentistrywater-based cements- Part 1: powder/liquid acid-base cements) [10]. KČ je testirana na univerzalnoj test mašini (Tinius Olsen, USA 5KN) sa brzinom utiskivača od $1 \mathrm{~mm} / \mathrm{min}$. po dužoj osi cilindričnog uzorka. Sila potrebna da polomi uzorak je beležena, a KČ izražena u MPa je izračunavana po formuli Cs $=4 \mathrm{P} / \pi \mathrm{d}^{2}$, gde je P maksimalna sila potrebna da polomi uzorak izražena $\mathrm{u} \mathrm{N}$, a d je prečnik uzorka u mm.

Za obradu dobijenih rezultata korišćeni su one-way ANOVA i post-hoc testovi. Nivo značajnosti je određen kao $\mathrm{p}<0,05$.

\section{REZULTATI}

Dobijeni rezultati su prikazani u Tabeli 1 i 2 i Grafikonu 1.

Najveće vrednosti KČ posle 24 dana pokazali su konvencionalni GJC FUJI IX $(38,56 \pm 13,31)$ i Ketak Universal $(40,77$ $\pm 7,96$ ), ali bez statističke razlike. Kalcijum-silikatni cementi su posle 24 sata pokazali niske vrednosti KČ, MTA Plus 5,91 \pm $0,28 \mathrm{MPa}$, a nCS $1,35 \pm 0,36 \mathrm{MPa}$, bez statističke značajnosti. Statistički značajna razlika je uočena između konvencionalnih GJC i CS cemenata $(\mathrm{p}<0,05)$.

I posle sedam dana najveće vrednosti KČ su pokazali FUJI IX

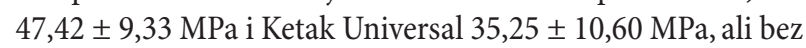
statistički značajne razlike među njima. KČ MTA Plus je 15,09 $\pm 2,77 \mathrm{MPa}$, a nCS $11,06 \pm 0,88 \mathrm{MPa}$, bez statistički značajne razlike između njih. Između konvencionalnih GJC i CS cemenata postoji statistički značajna razlika $(\mathrm{p}<0,05)$.

Posle 28 dana uočena je stagnacija vrednosti KČ za konvencionalne GJC FUJI IX 48,03 — 7,82 MPa i Ketak Universal 36,65 $\pm 11,13 \mathrm{MPa}$. Nije bilo statistički značajne razlike između GJC. Posle četiri nedelje uočava se porast vrednosti KČ za kalcijumsilikatne cemente, MTA Plus 16,47 $\pm 1,89 \mathrm{MPa}$, a nCS 14,39 \pm 1,63 MPa, ali bez statistički značajne razlike između njih. Između konvencionalnih GJC i CS cemenata postoji statistički značajna razlika $(\mathrm{p}<0,05)$ i posle 28 dana.

\section{DISKUSIJA}

KČ je indirektna mera vezivanja i čvrstoće materijala $[11,12]$ i važno je svojstvo koje može uticati na kliničke performanse materijala [13]. Ovaj faktor igra važnu ulogu u tretmanu furkacionih perforacija, gde su cementi direktno izloženi delovanju okluzalnih sila [14].

U literaturi se uočavaju velike varijacije u rezultatima, jer na njih utiču brojni faktori. Cilindričan oblik uzoraka je pogodan, ali savršenost površine uzoraka i intimni kontakt između uzorka i uređaja za testiranje je teško postići [8]. Osim toga, na reprezentativnost rezultata utiču veličina i oblik uzorka, priprema uzorka i vreme hidratacije, odnos voda/prah, tehnika mešanja, pritisak prilikom kompakcije, kao i vlažnost i temperatura prostorije $[15,16]$. Ovi faktori utiču na fizička svojstva materijala, pa i na KČ.

Konvencionalni GJC su u širokoj upotrebi u kliničkoj praksi kao cementi ili kao restaurativni materijali. Mnoga istraživanja su rađena u cilju poboljšanja mehaničkih i bioloških osobina GJC inkorporacijom bioaktivnih keramičkih čestica, staklenog praha i sl. Dodavanje Zn je pokazalo da ima stimulativni efekat na formiranje kosti u in vitro i in vivo uslovima, kao i na antibakterijsku aktivnost, slično srebru. Dodavanje $\mathrm{MgO}$ je poboljšalo ćelijsku proliferaciju [3]. Titanijum-dioksid se dodaje jer je hemijski stabilan, biokompatibilan i ima antibakterijska svojstva, a u nanoformulaciji je pokazao i značajnu aktivnost protiv Streptococcus mutansa [8].

$\mathrm{U}$ ovom radu je potvrđeno, kao i kod drugih istraživača, da se cementna reakcija nastavlja i posle jednog dana, jer se u cementnom matriksu odvijaju poprečne veze [3]. Shiozawa [17] ističe da se maturacija cementa, odnosno acido-bazna reakcija nastavlja u prvoj nedelji, što se ogleda u porastu KČ, a onda ostaje na tom nivou sledećih 12 meseci. Ovi nalazi su u saglasnosti sa rezultatima ovog istraživanja, gde između 7 i 28 dana nije došlo do daljeg porasta vrednosti KČ konvencionalnih glasjonomer cemenata.

KČ se smatra jednom od glavnih fizičkih karakteristika hidrauličnih cemenata i u korelaciji je sa stepenom hidratacije [2], a reakcija hidratacije je ključna za očvršćavanje hidrauličnih silikatnih cemenata.

KČ kalcijum-silikatnih cemenata je inicijalno, posle 24 sata, niska. Vezivanje i jačina hidrauličnih cemenata zavisi od formiranja CSH gela i etringita (hidrirani kalcijum-sulfoaluminat) na mestima nukleacije kalcijum-hidroksilnih kristala [18] (Oloomi i sar. 2013). Prisustvo ili manjak ovih kristalnih formacija (ettringite crystals) u različitim formulacijama kalcijum-silikatnih cemenata su verovatno razlog nižih/različitih vrednosti KČ među njima [2]. U ISO standardu još uvek nisu definisane vrednosti KČ za materijale za prekrivanje pulpe ili perforacija, pa se sve svodi na preporuku da se materijali porede sa vrednostima stresa koji nastaje usled kondenzacije amalgama [19]. Posle sedam dana vrednosti KČ kalcijum-silikatnih cemenata izrazito se povećava, a kao posledica dalje hidratacije cementa, KČ nCS i dalje raste, posle 28 dana.

Razlike u vrednostima KČ između materijala koji imaju sličan ili pak isti sastav može se objasniti razlikama u veličini čestica $[11,19]$, kao i uslovima eksperimenta. Tako Akbari i sar. [6] nalaze da je KČ za White MTA (Angelus, Brazil) 1,16 MPa posle 24 sata, a 2,19 MPa posle sedam dana, dok Natale i sar. [20] nalaze da mu je KČ posle sedam dana $18 \mathrm{Mpa}$. Noh i sar. 
[21] nalaze da je WMTA (ProRoot MTA, USA) posle 24 sata imao prosečne vrednosti 19,41, a posle sedam dana 46,18 MPa, dok Basturk i sar. [16] iznose vrednosti i do 84,17 MPa posle četiri dana za ProRoot MTA. Mikrostruktura i homogenost cementa utiču na njegovu čvrstoću, jer sitnije čestice imaju veću sposobnost apsorpcije vlage.

Ručno mešanje i unošenje materijala takođe može uticati na neadekvatnu hidrataciju zbog ograničenog formiranja mikropora unutar materijala, što kompromituje prodor vode u hidrat materijala. Mitchell i Douglas ističu da ručno mešani cementi imaju slabiju čvrstoću, zbog zarobljenog vazduha, dok inkapsulirani cementi koji se mešaju i centrifugiraju imaju veću KČ $[22,16]$.

Nanostrukturni materijali imaju čestice koje ne prevazilaze veličinu od $100 \mathrm{~nm}$ (najčešće između 5 i $50 \mathrm{~nm}$ ), ali zato imaju i do deset puta veću interaktivnu površinu, što utiče na povećano formiranje etringit kristala [23]. Nanostrukture pokušavaju da reše jedan od ključnih problema endodontskih cemenata kao što je vreme vezivanja. Eksperimenti ukazuju na to da kod praktično svih nanoprahova kinetika apsorpcije i desorpcije može biti unapređena jednostavno smanjenjem veličine zrna [14].
Usavršavanje materijala koji bi mogli da se koriste kao biološke „zamene“ kosti danas je jedna od najznačajnijih i najaktivnijih oblasti istraživanja biomaterijala. Biokompatibilnost $\mathrm{i}$ bioaktivnost ovih materijala obezbeđuje interakciju sa biološkim sistemima. Bioaktivni materijali kakvi su kalcijum-silikatni cementi, posebno sa nanostrukturom, stimulišu regeneraciju oštećenih tkiva, a time i obnavljanje funkcije oštećenih tkiva ili organa [7].

\section{ZAKLJUČAK}

Nulta hipoteza da nema razlike u KČ između konvencionalnih i kalcijum-silikatnih cemenata je odbačena. KČ za konvencionalne glasjonomer cemente je bila značajno viša posle 24 sata, a rasla je posle sedam dana i ostala ista 28 dana. MTA Plus je pokazao veću KČ posle 24 sata i sedam dana u odnosu na novosintetisani nanostrukturni kalcijum-silikatni cement (nCS), ali ove vrednosti su se izjednačile posle 28 dana. KČ kalcijum-silikatnih cemenata značajno raste u funkciji vremena i sa hidratacijom cemenata. 